\title{
The Application of 5E Learning Cycle Model Towards Students Learning Activities on Salt Hydrolysis Subject Material in Grade XI SMAN 1 Pakem Academic Year 2019/2020
}

\author{
Nisrina Zahira Putri Irawan ${ }^{\mathrm{a}, *}$, Muhaimin $^{\mathrm{a}}$, Krisna Merdekawati $^{\mathrm{a}}$ \\ aUndergraduate Program in Chemistry Education, Faculty of Mathematics and Natural Sciences, \\ Universitas Islam Indonesia, Sleman, Special Region of Yogyakarta \\ $a^{*}$ Corresponding Author: nisrina.irawan@students.uii.ac.id
}

Received: December 22, 2020; Accepted: July 13, 2021; Published: October 15, 2021

\begin{abstract}
This study aims to determine whether there is a significant difference between the application of the 5E Learning Cycle model and conventional learning towards learning activities on salt hydrolysis subject material. The type of research used experimental research. The study population was all students of grade XI at SMA Negeri 1 Pakem in the academic year 2019/2020, totaling 5 classes. The research sample used XI MIPA 1 class as the experimental class and XI MIPA 2 class as the control class which was taken by purposive sampling technique. Data collection through non-test techniques in the form of questionnaires and observations. Data analysis techniques on learning activity variables used Parametric Statistics Independent Sample T-Test for observational data and Non-Parametric Statistics for the Mann-Whitney test for questionnaire data. Based on the results of the study, it can be concluded that there is a significant difference between students who take learning with the $5 \mathrm{E}$ Learning Cycle model and students who take conventional learning towards learning activities.
\end{abstract}

Keywords: 5E Learning Cycle Model, Learning Activities, Salt Hydrolysis.

\section{INTRODUCTION}

Curriculum 2013 is a curriculum that is currently applied to the education system in Indonesia. The curriculum 2013 is implemented by active learning based on a scientific approach that aims to improve learning outcomes in terms of knowledge, skills, and attitudes of students. Therefore, it is expected that each learning activity carried out can provide a good learning process and results [1].

There are two factors that can affect learning outcomes, namely $70 \%$ comes from the conditions that exist within students (internal factors) and 30\% comes from the students' environment (external factors) [2]. One of these external factors, namely learning activities. The success of a lesson depends on how big the participation of the students in the lesson, the more active students take part in the lesson, the more successful these lessons are. Learning outcomes will not be optimal without learning activities [3].

The implementation of learning using the curriculum 2013 still finds problems that can have an impact on learning processes and outcomes. The implementation of curriculum 2013 presents various challenges related to teaching materials, learning strategies, assessment, and evaluation, until the development of technology and information [1]. Most of the teachers still choose conventional learning methods which results in low learning activities of students. According to the results of interviews from the teacher and several students at SMAN 1 Pakem Yogyakarta, several problems were found related to the students' chemistry learning process. The teacher has tried various methods so that the process 
Irawan, N.Z.P., Muhaimin, Merdekawati, K

and learning outcomes of students' chemistry learning can be achieved optimally. Moreover, the characteristics of chemistry subjects generally are abstract and many calculations. However, learning methods such as lectures, question and answer, and also exercises that have been attempted by the teacher still make students have a few interactions actively in learning, both to the teachers and to their friends. It happened because the method is still dominated by teacher activity. As a result, students consider that chemistry is a difficult subject, especially in solving calculation problems and determining the equations of chemical reactions, especially in salt hydrolysis material.

The 5E Learning Cycle model is a model designed so that students can learn actively. The 5E Learning Cycle consists of several phases that can make students learn actively, such as the Engagement phase which can arouse students' interest and curiosity so that they are provoked to carry out learning activities. In addition, this model will also establish interactions between students because learning is carried out in groups to get a source of knowledge through the Exploration and Explain phase. The other advantage of this model is students have some opportunities to develop their thinking and analytical skills to solve problems in the Elaboration phase [4].

The 5E Learning Cycle model is expected to help students have good learning outcomes through various learning activities. The teacher's role is as a facilitator in applying the $5 \mathrm{E}$ Learning Cycle model, which is to help students when experiencing difficulties and to anticipate when students have misconceptions during the lesson. Students learning activities are very influential on the learning outcomes of students in the class. Students who are active in the class will influence the motivation of other students to take an active role in the learning process. Thus, students who have high activity will also get high learning outcomes [5]. The purpose of this study is to determine whether or not there is a significant difference in the application of the 5E Learning Cycle model on learning activities of students at Grade XI SMAN 1 Pakem Yogyakarta academic year 2019/2020 in salt hydrolysis material.

\section{METHODS}

\section{Research Design and Variables}

The type of this research was experimental research using Quasi-Experimental Design, with a Posttest Only with Nonequivalent Group Design. This study involved two classes, namely the experimental class as the class which was treated with the 5E Learning Cycle model and the control class which was treated with conventional learning methods. Both of the classes were selected nonrandomly. Furthermore, each class is given a posttest to measure the learning activities of students. The research design is described in Table 1.

TABLE 1. Experimental Research Design

\begin{tabular}{ccc}
\hline Class & Treatment & Final Condition \\
\hline Experimental Class & $X$ & $\mathrm{Y}_{2}$ \\
Control Class & - & $\mathrm{Y}_{2}$ \\
\hline
\end{tabular}

$X=$ Treatment with 5E Learning Cycle Model

$\mathrm{Y}_{2}=$ Post-test for experimental class and control class

This study uses two variables, namely the independent variable and the dependent variable. The independent variable in this study is the Learning Cycle $5 \mathrm{E}$ model which is applied to the experimental class. This model consists of 5 phases, namely the Engagement, Exploration, Explain, Elaboration, and Evaluation. The phases of the 5E Learning Cycle model can be seen in Table 2 [6]. While the dependent variable used in this study is student learning activities. Learning activities are all forms of activities both physically and mentally that are related to each other as an effort for students to gain an understanding knowledge, build and change attitudes or behavior, and to develop skills in the learning process $[7,8]$. The aspects of learning activities that are studied include aspects of Visual Activities, Oral Activities, Writing Activities, Mental Activities, and Emotional Activities [7]. The material taught in this research is salt hydrolysis subject matter. 
Irawan, N.Z.P., Muhaimin, Merdekawati, K

TABLE 2. Phases of the 5E Learning Cycle Model

\begin{tabular}{cl}
\hline $\begin{array}{c}\text { Phases of the } \\
\text { 5E Learning } \\
\text { Cycle Model }\end{array}$ & \multicolumn{1}{c}{ Activity } \\
\hline Engagement & $\begin{array}{l}\text { The teacher gives several questions related to the material to be studied which } \\
\text { can foster the interest and curiosity of the students. } \\
\text { Exploration } \\
\text { Students are invited to make predictions or temporary knowledge related to things } \\
\text { to be learned on that day through practicum activities, group discussions, and work } \\
\text { on student worksheets. }\end{array}$ \\
Explain & $\begin{array}{l}\text { Students are encouraged to clarify, explain the concepts, and prove what they } \\
\text { have got from the exploration activities according to their understanding and use } \\
\text { their own sentences through discussions between groups and the teacher. }\end{array}$ \\
Elaboration & $\begin{array}{l}\text { Students have found the correct concepts from the previous phase, and then the } \\
\text { teacher needs to develop students of these concepts by applying them to new } \\
\text { situations and increasing the level of difficulty. }\end{array}$ \\
Evaluation & $\begin{array}{l}\text { The teacher evaluates the level of understanding and mastery of students' } \\
\text { concepts in the knowledge domain after going through the elaboration phase. }\end{array}$ \\
\hline
\end{tabular}

Place, Time, and Subject Research

This research was held at SMA Negeri 1 Pakem which is located at Jalan Kaliurang Km. 17.5, Pakembinangun, Pakem District, Sleman Regency, Special Region of Yogyakarta. This research was conducted in January 2020-March 2020. The subjects used in this research consisted of two classes, namely class XI MIPA 1 as the experimental class and class XI MIPA 2 as the control class. Each class consists of 31 people. The sampling technique used in this study was the purposive sampling technique. Purposive sampling is a sampling technique based on certain considerations [9].

\section{Data Collections}

This study uses non-test methods to obtain data on student learning activities. Before data collection was carried out, the instruments must meet the requirements of validity content. Content validity is carried out in order to specifically measure an instrument based on its suitability with the content or subject matter given. The instruments had been validated by validators that have expertise in their field [10]. The instruments used in this study were observation sheets and questionnaires. After that, learning activity data were collected through observation techniques and filling out self-assessment questionnaires for learning activities. Observation of students learning activities is carried out during the learning process, while the self-assessment of students' learning activities is carried out at the end of the lesson.

\section{Data Analysis}

Data analysis begins with a prerequisite test consisting of a normality test and a homogeneity test using the SPSS v.16 software. The normality test is used to determine whether the data is normally distributed or not. The normality test in this study used the Kolmogorov-Smirnov test. Meanwhile, the homogeneity test is used to find out whether the data in each sample is homogeneous or not. The homogeneity test in this study used the Levene Statistic test. The data has been normally distributed and homogeneous if the significance value obtained is $>0.05$. The result of the prerequisite tests in this study is presented in Table 3.

If the data that has been obtained meets the prerequisite test, then the determination of the hypothesis test in this study uses parametric statistical analysis with the Independent Sample T-Test. Meanwhile, if the data does not meet the prerequisite tests (normality test and homogeneity test), then the determination of the hypothesis test in this study uses non-parametric statistical analysis with the Mann-Whitney $U$ Test. The decision of the hypothesis test is determined based on the Ho rejected or acceptance criteria. If the significance value obtained $<0.05$ then Ho is rejected. However, if the significance value obtained is $>0.05$ then Ho is accepted. The conclusions from the results of the hypothesis testing are as follows: 
Irawan, N.Z.P., Muhaimin, Merdekawati, K

Ho: $\quad$ There is no significant difference in the application of the 5E Learning Cycle model towards learning activities in class XI students of SMAN 1 Pakem on the subject matter of salt hydrolysis.

$\mathrm{Ha}$ : There is a significant difference in the application of the 5E Learning Cycle model towards learning activities in class XI students of SMAN 1 Pakem on the subject matter of salt hydrolysis.

In addition, observational data and self-assessment questionnaires are also determined the criteria for each aspect of learning activities using a rating scale based on the predetermined assessment guidelines [11]. The scale of the assessment criteria for each aspect of student learning activities can be seen in Table 3.

TABLE 3. Criteria of Students Learning Activities for Each Aspect

\begin{tabular}{cccc}
\hline \multicolumn{2}{c}{$\begin{array}{c}\text { Observation of Learning Activities } \\
\text { Data }\end{array}$} & \multicolumn{2}{c}{$\begin{array}{c}\text { Self-Assessment of Learning Activities } \\
\text { Data (Questionnaires) }\end{array}$} \\
Interval Score & Criteria & Interval Score & Criteria \\
\hline $77,5-93,0$ & Very Good & $100,75-124,00$ & Very Good \\
$62,0-77,5$ & Good & $77,50-100,75$ & Good \\
$46,5-62,0$ & Sufficient Good & $54,25-77,50$ & Sufficient Good \\
$<46,5$ & Less Good & $<54,25$ & Less Good \\
\hline
\end{tabular}

\section{RESULT AND DISCUSSION}

Based on the results of research regarding the application of the Learning Cycle 5E model in the experimental class and its comparison with the conventional method in the control class at SMAN 1 Pakem on learning activities on salt hydrolysis material, data has been obtained from the results of filling out observation sheets and self-assessment questionnaires. Based on the results of the normality test on the learning activities questionnaire as listed in Table 4, the experimental class significance value is 0.076 which means that the significance value is $>0.05$. While the significance value of the control class is 0.011 , which means that the significance value of the control class is $<0.05$. This means that the data in the experimental class are normally distributed, but the control class is abnormal. So, the learning activities questionnaire data did not meet the prerequisite test so that the hypothesis test was continued with the Non-Parametric Statistical analysis using the Mann-Whitney $U$ test.

The prerequisite test results from the observation data of learning activities obtained a significance value from the normality test in the experimental class and control class of 0.200 and the significance value of the homogeneity test results of 0.511 as can be seen in Table 4 . This means that the significance value is $>0.05$, so the data is normally distributed and homogeneous. Thus, the data has met the prerequisite test and the learning activity observation sheet data can be continued with a hypothesis test using Parametric Statistical analysis, the Independent Sample T-Test, as listed in Table 4.

TABLE 4. Prerequisite Test Results (Normality and Homogeneity Test)

\begin{tabular}{cccccc}
\hline Data & Class & \multicolumn{2}{c}{ Normality } & \multicolumn{2}{c}{ Homogeneity } \\
& Sig. & Result & Sig. & Result \\
\hline Observation of Learning & Experiment & 0,200 & Normal & \multirow{2}{*}{0,511} & \multirow{2}{*}{ Homogeneous } \\
Activities & Control & 0,200 & Normal & & \\
Self-Assessment of & Experiment & 0,076 & Normal & & \\
Learning Activities & Control & 0,011 & Abnormal & 0,793 & Homogeneous \\
(Questionnaires) & & & \\
\hline
\end{tabular}

Based on the results of hypothesis testing on the observation sheet data using the Independent Sample T-Test, data obtained in the form of a significance value of 0.029 . This shows that the significance value $<0.05$ so that $\mathrm{Ho}$ is rejected. As for the results of testing the hypothesis on the questionnaire data using the Mann-Whitney test, the data obtained is a significance value of 0.006 . This shows that the significance value $<0.05$ so that $\mathrm{Ho}$ is rejected. Thus, it can be concluded that there is a 
significant difference between the application of the Learning Cycle $5 \mathrm{E}$ model with conventional learning methods on the learning activities of students on the subject matter of salt hydrolysis, as listed in Table 5.

TABLE 5. Hypothesis Test Result

\begin{tabular}{cccc}
\hline Data & Significance & Decision $\mathbf{H}_{\mathbf{o}}$ & Conclusion \\
\hline $\begin{array}{c}\text { Observation of Learning } \\
\text { Activities }\end{array}$ & 0,029 & $\mathrm{H}_{\mathrm{o}}$ rejected & $\begin{array}{c}\text { There is a significant } \\
\text { difference }\end{array}$ \\
$\begin{array}{c}\text { Self-Assessment of Learning } \\
\text { Activities (Questionnaires) }\end{array}$ & 0,006 & $\mathrm{H}_{\mathrm{o}}$ rejected & $\begin{array}{c}\text { There is a significant } \\
\text { difference }\end{array}$ \\
\hline
\end{tabular}

The descriptions of the results of research regarding the application of the Learning Cycle 5E model in the experimental class and its comparison with the conventional method in the control class at SMAN 1 Pakem in salt hydrolysis material on students' learning activities are generally presented in Table 6.

TABLE 6. Description Data

\begin{tabular}{ccccc}
\hline Data & Class & Highest Score & Lowest Score & Average Score \\
\hline Self-Assessment of & Experiment & 80,00 & 61,00 & 71,77 \\
Learning Activities & Control & 79,00 & 58,00 & 69,29 \\
(Questionnaires) & Experiment & 37,00 & 16,67 & 28,60 \\
Observation of & Control & 36,67 & 15,67 & 25,16 \\
Learning Activities & Con
\end{tabular}

Based on Table 6, the results of observations of students' learning activities, the average value in the experimental class was 28.6 and the average value in the control class was 25.16. The same thing was also obtained from the data from the results of self-assessment of students' learning activities, the average value in the experimental class was 71.77 and the average value in the control class was 69.29. This shows that the value of learning activities in the experimental class is higher than the value of learning activities in the control class so that there is a difference in the average value of learning activities between the application of the $5 \mathrm{E}$ Learning Cycle model and conventional learning methods.

TABLE 7. Result of the Observation of Students Learning Activities for Each Aspect

\begin{tabular}{|c|c|c|c|c|}
\hline \multirow{2}{*}{ Aspect } & \multicolumn{2}{|c|}{ Experimental Class } & \multicolumn{2}{|c|}{ Control Class } \\
\hline & Average Score & Criteria & Average Score & Criteria \\
\hline Visual Activities & 54,33 & $\begin{array}{c}\text { Sufficient } \\
\text { Good }\end{array}$ & 52,33 & Sufficient Good \\
\hline Oral Activities & 62,80 & Good & 52,07 & Sufficient Good \\
\hline Writing Activities & 66,00 & Good & 62,00 & Good \\
\hline Mental Activities & 64,00 & Good & 56,56 & Sufficient Good \\
\hline Emotional Activities & 74,00 & Good & 59,33 & Sufficient Good \\
\hline
\end{tabular}

TABLE 8. Result of the Self-Assessment of Students Learning Activities for Each Aspect

\begin{tabular}{ccccc}
\hline \multirow{2}{*}{ Aspect } & \multicolumn{2}{c}{ Experimental Class } & \multicolumn{2}{c}{ Control Class } \\
& Average Score & Criteria & Average Score & Criteria \\
\hline Visual Activities & 86,75 & Good & 84,50 & Good \\
Oral Activities & 83,00 & Good & 84,63 & Good \\
Writing Activities & 84,00 & Good & 82,00 & Good \\
Mental Activities & 102,50 & Very Good & 99,50 & Good \\
Emotional Activities & 86,50 & Good & 60,50 & Sufficient Good \\
\hline
\end{tabular}




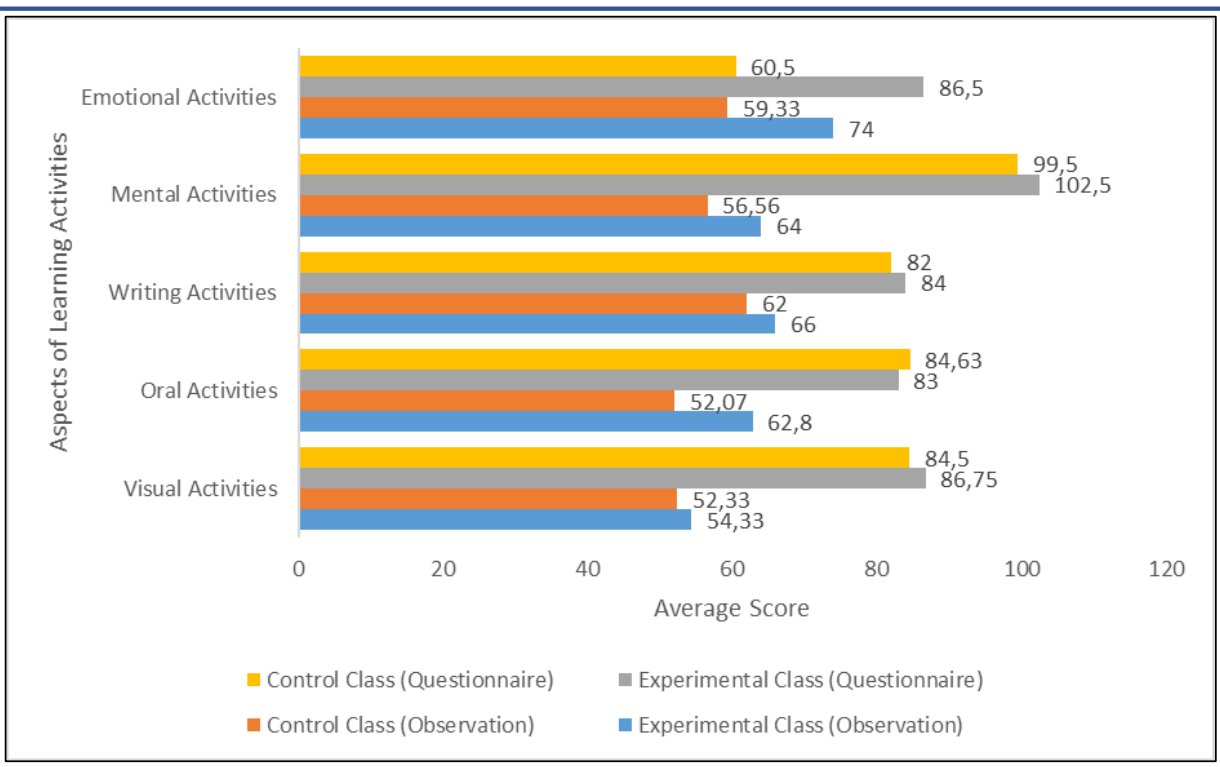

FIGURE 1. The comparison of learning activities assessments between the experimental class and control class

Based on the observation and self-assessment result, the application of the $5 \mathrm{E}$ Learning Cycle model in the experimental class can show differences from the average score of learning activities in the aspects of Visual Activities, Oral Activities, Writing Activities, Mental Activities, and Emotional Activities which are shown higher than the average score in every aspect of learning activities studied from the application of conventional methods in the control class. For more details, the comparison of learning activities for each aspect between the experimental class and the control class is presented in Figure 1. Furthermore, the criteria of learning activities that were achieved from experimental class and control class based on observation and self-assessment (questionnaire) data are presented in Table 7 and Table 8.

The difference in the average score of learning activities that appears in the aspects of Visual Activities, Oral Activities, Writing Activities, Mental Activities, and Emotional Activities between the experimental class and the control class occurs as a result of each phase of the activities carried out in the application of the 5E Learning Cycle model. The engagement and exploration learning phases made students know the importance of studying chemistry subjects and became interested in wanting to learn more about salt hydrolysis. This makes students emotionally active. Furthermore, in the exploration phase, students were also actively looking for sources of knowledge through reading textbooks and information from the internet, and also directly observing the phenomenon of salt hydrolysis through practicum activities. These activities make students active from the aspect of visual activities. Then, the impact of visual activities during the exploration phase also creates writing activities. In the exploration phase, students recorded the information they had obtained so that from the application of the Learning Cycle 5E model, students did not only record material obtained from the teacher, which was carried out in the explain phase.

Furthermore, the engagement and exploration learning phases also triggered students to do oral activities such as discussing with friends and asking the teacher. In addition, oral activities also appear when students enter the explain phase because, at this phase, students convey their opinions and initial knowledge obtained from the exploration phase. Finally, the elaboration phase triggers students to be challenged to solve problems and develop their thinking skills in solving more complicated questions than the previous phases. This phase causes the students learning activities in terms of mental activities.

\section{CONCLUSION}

Based on the result of this research, it can be concluded that there is a significant difference in students learning activities between the application of the 5E Learning Cycle Model and the conventional 
learning methods on the salt hydrolysis subject material in Grade XI SMAN 1 Pakem academic year 2019/2020.

\section{ACKNOWLEDGEMENT}

A big thanks are given to Mrs. Mustianti, S.Pd. as a chemistry teacher in grade $\mathrm{XI}$ and the entire ranks of SMAN 1 Pakem Yogyakarta for their willingness to be involved in this research.

\section{REFERENCES}

1. Nurdyansyah \& Fahyuni, Inovasi Media Pembelajaran Sesuai Kurikulum 2013 (Nizamial Learning Center, Sidoarjo, 2016).

2. $\quad$ R.A. Sani, Strategi Belajar Mengajar (Rajawali Press, Depok, 2019).

3. T. Sulistiyowati, S.B. Utomo, dan Y. Sri, Jurnal Pendidikan Kimia (JPK), 3, 4, 1-6 (2014).

4. H. Senindra, M. Muslim, dan A. Fathurohman, Jurnal Inovasi dan Pembelajaran Fisika (JIDPF), 3, 1, 1-7 (2016).

5. Sarianti, Aminuyati, \& H. Syahrudin, Jurnal Pendidikan dan Pembelajaran Untan Pontianak (JPPUP), 4, 12, 1-10 (2015).

6. Ngalimun, M. Fauzani, \& A. Salabi, Strategi dan Model Pembelajaran (Aswaja Pressindo, Yogyakarta, 2018).

7. A.M. Sardiman, Interaksi dan Motivasi Belajar Mengajar (PT. Raja Grafindo Persada, Jakarta, 2005).

8. O. Hamalik, Proses Belajar Mengajar (Bumi Aksara, Jakarta, 2008).

9. Sugiyono, Metode Penelitian Pendidikan: Pendekatan Kuantitatif, Kualitatif, dan R\&D (Alfabeta, Bandung, 2009).

10. S. Arikunto, Dasar-Dasar Evaluasi Pendidikan (Bumi Aksara, Jakarta, 2005)

11. Depdiknas, Juknis Penyusunan Perangkat Penilaian Afektif di SMA (Direktorat Pembinaan Sekolah Menengah Atas, Jakarta, 2010). 